\title{
BM] open A survey of early health effects of the Eyjafjallajökull 2010 eruption in Iceland: a population-based study
}

\author{
Hanne Krage Carlsen, ${ }^{1}$ Thorarinn Gislason, ${ }^{2,3}$ Bryndis Benediktsdottir, ${ }^{2,3}$ \\ Thorir Bjorn Kolbeinsson, ${ }^{4}$ Arna Hauksdottir, ${ }^{1}$ Throstur Thorsteinsson, ${ }^{5}$ \\ Haraldur Briem ${ }^{6}$
}

To cite: Carlsen HK, Gislason T, Benediktsdottir B, et al. A survey of early health effects of the Eyjafjallajökull 2010 eruption in Iceland: a population-based study. BMJ Open 2012;2:e000343. doi:10.1136/

bmjopen-2011-000343

- Prepublication history for this paper is available online. To view this file please visit the journal online (http://dx. doi.org/10.1136 bmjopen-2011-000343).

Received 15 November 2011 Accepted 6 February 2012

This final article is available for use under the terms of the Creative Commons Attribution Non-Commercial

${ }^{1}$ Centre of Public Health Sciences, University of Iceland, Reykjavik, Iceland

${ }^{2}$ Faculty of Medicine, University of Iceland, Reykjavik, Iceland

${ }^{3}$ Department of Respiratory Medicine and Sleep, Landspitali University Hospital, Reykjavik, Iceland ${ }^{4}$ Primary Health Care Centre of South Iceland, Hella, Iceland

${ }^{5}$ Environment and Natural Resources and Institute of Earth Sciences, University of Iceland, Reykjavik, Iceland ${ }^{6}$ Centre for Health Security and Communicable Disease Control, Directorate of Health, Reykjavik, Iceland

Correspondence to Dr Haraldur Briem; hbriem@landlaeknir.is

\section{ABSTRACT}

Objective: To estimate physical and mental health effects of the Eyjafjallajökull volcanic eruption on nearby residents.

Design: Cross-sectional study.

Setting: The Icelandic volcano Eyjafjallajökull erupted on 14 April 2010. The eruption lasted for about 6 weeks and was explosive, ejecting some 8 million tons of fine particles into the atmosphere. Due to prevailing winds, the ash spread mostly to the south and south-east, first over the rural region to the south, later over the Atlantic Ocean and Europe, closing European air space for several days.

Participants: Residents $(n=207)$ of the most ashexposed rural area south and east of the volcano.

Methods: The study period was from 31 May to 11 June 2010. Participants were examined by a physician. To ascertain respiratory health, standardised spirometry was performed before and after the use of a bronchodilator. All adult participants answered questionnaires about mental and physical health, their children's health and the use of protective equipment.

Results: Every other adult participant reported irritation in eyes and upper airway when exposed to volcanic ash. Adults $(n=26)$ and children $(n=5)$ with pre-existing asthma frequently reported worsening of their symptoms. No serious health problems requiring hospitalisation could be attributed to the eruption. The majority of the participants reported no abnormal physical or mental symptoms to the examining physician. Compared to an age- and gender-matched reference group, the ash-exposed participants reported lower smoking rates and were less likely to have ventilation impairment. Less than $10 \%$ of the participants reported symptoms of stress, anxiety or depression.

\section{Conclusions: Short-term ash exposure was} associated with upper airway irritation symptoms and exacerbation of pre-existing asthma but did not contribute to serious health problems. The exposure did not impair respiratory function compared to controls. Outdoor use of protective glasses and face masks was considered protective against irritation in eyes and upper airway.

\section{ARTICLE SUMMARY}

\section{Article focus}

- Exposure to volcanic ash and gases can have adverse effects on respiratory health.

- Natural hazards, such as volcanic eruptions, can be stressful events.

- Value of preventive measures for those exposed to a volcanic eruption.

Key messages

- The short-term effects of ash exposure were associated with irritation in eyes and upper airway and exacerbation of pre-existing asthma but did not contribute to serious health problems or impair respiratory function as compared to controls.

- Participants with pre-existing respiratory and mental conditions need special attention and are more prone to developing symptoms following exposure to volcanic eruptions and volcanic ash.

- The use protective glasses and face masks prevented or relieved irritation symptoms from the eyes and upper airway.

\section{INTRODUCTION}

On 14 April 2010, an explosive summit crater eruption began in Eyjafjallajökull (Eyjafjalla Glacier), a volcano that is situated in south Iceland (figure 1). In the early phases of the eruption, fine-grained ash was ejected up to $10 \mathrm{~km}$ into the atmosphere, disturbing air traffic in Europe for days. In Iceland, the rural regions south and south-east of the volcano were heavily exposed to falling ash. The volcano ejected some 250 million tons of ash, of which 8 million tons of particles were $2.8-28 \mu \mathrm{m}$ in diameter. $^{1-5}$ Particles with a diameter of $<10 \mu \mathrm{m}$ are inhalable and can compromise respiratory health. Despite the falling ash that changed day to night, many inhabitants, mostly farmers, remained in the area to work on their farms and tend their livestock. 


\section{ARTICLE SUMMARY}

Strengths and limitations of this study

- The whole population living within a confined area close to the volcano was contacted, and the response rate was high (93\%) minimising the risk of selection bias, though some sensitive individuals had probably left the area, and some older individuals did not participate in the survey.

- Standardised methods were used in measuring respiratory function, and questionnaires were also standardised, allowing for comparisons with other studies.

- Results from the spirometry were compared to those from an age- and gender-matched Icelandic control group from a previous study, which had been performed using identical methods.

- The population was small ( $\mathrm{N}=207)$, and due to stressful circumstances during the test period, not all participants completed the questionnaire, which limited the statistical power of our analyses.

Apart from the immediate life-threatening hazards following a volcano eruption, such as pyroclastic flows, mudslides and glacial outburst floods, several other health risks are associated with living close to an active volcano. ${ }^{6}$ Short-term exposure to volcanic gases can trigger asthma attacks and has been associated with respiratory morbidity and mortality and increased irritation of the respiratory tract. ${ }^{7}$ Exposures for longer time periods to volcanic ash and gases have been associated with increases in cardiovascular symptoms ${ }^{8}$ and increased rates of chronic bronchitis and other respiratory symptoms, ${ }^{9}{ }^{10}$ also in children. ${ }^{11}$ Symptoms of skin and eye irritation have also been reported. ${ }^{12}$ The chemical and physical properties of volcanic ash vary a great deal between eruptions and volcanoes, making it

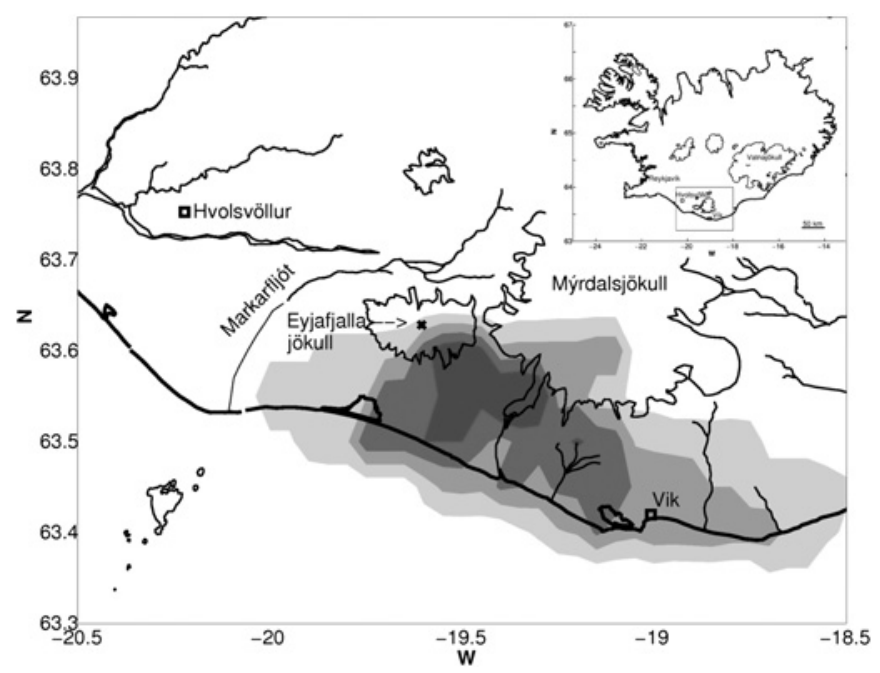

Figure 1 Map of the study area, which reached from just west of Eyjafjallajökull to Vík in the east. The shading illustrates duration and intensity of the ash plume. The darkest areas represent an estimated ash deposition of $>500 \mathrm{~g} / \mathrm{m}^{2}$, and around Vík, the deposition is estimated around $200 \mathrm{~g} / \mathrm{m}^{2}$. difficult to generalise about the toxicity of ash from individual eruptions. ${ }^{12}$

Volcanic eruptions are violent natural disasters that impose a threat to health as well as to livestock and property. During eruptions, the population may have to be evacuated, depending on risk assessment, and uncertainty and stress experienced during the eruption can influence mental well-being. ${ }^{13}{ }^{14}$ The aims of this study were to examine medically the most exposed population and to evaluate possible acute physical and mental health effects associated with the Eyjafjallajökull eruption. In addition, the effectiveness of protective measures taken against inhaling ash and eye exposure was evaluated by asking the participants for their subjective experience of the measures.

\section{METHODS}

\section{The study area of the volcanic eruption}

The volcanic eruption of the Eyjafjallajökull volcanic system began on 20 March 2010 with a small flank eruption, which produced negligible ash. After a day of no volcanic activity, an eruption started within the Eyjafjallajökull caldera on 14 April. $^{15}$ This phase was explosive, sending fine-grained, phreatomagmatic ash into the atmosphere. The eruption lasted some 6 weeks, until the end of May 2010. Ash exposure around the volcano was estimated using information about the eruption plume from satellite images (coarse time resolution), information about the emission intensity, ${ }^{1}$ and information from observations on the ground. ${ }^{16}$ Model calculations using FLEXPART $^{5}$ gave similar distribution for the deposited ash, with maximum deposition around $1000 \mathrm{~g} / \mathrm{m}^{2}$ (near the vent of the volcano) and about $200 \mathrm{~g} / \mathrm{m}^{2}$ near Vík. ${ }^{4}$ During that time, the wind direction was predominantly west and north-west, therefore most of the ash fall was to the south and south-east of the volcano (figure 1). In this study, we included inhabitants of the area between the River Markarfljót and the village of Vík as they were most exposed. Most inhabitants are farmers, and many also have income from tourism.

\section{The volcanic ash}

The ash was trachyandesitic, $58 \%$ silica by mass, but contained very little quartz, and no cristobalite was detected. ${ }^{1-5}$ In ash samples collected during the first 3 days of the eruption, upwards of $25 \%$ of particles by mass were $<10 \mu \mathrm{m}$ in diameter $\left(\mathrm{PM}_{10}\right)$ and therefore inhalable. The fraction of fine particles was lower for ash ejected later in the eruption, ${ }^{1}$ but still the amount of ash produced was considerable, and the fine-grained ash was also easily resuspended. The concentration of airborne particulate matter frequently exceeded the WHO guideline values for $\mathrm{PM}_{10}$ during the eruption. ${ }^{4}$

A network of diffusion tubes in the ground area showed no evidence of fumigation by sulphur dioxide, the predominant volcanic gas in the ash plume, in the last 3 weeks of the eruption (Personal communication: Peter Baxter, 2010). 
Target population and recruitment

During the eruption, some 223 individuals lived in the study area and were exposed to ash fall. All the inhabitants were invited to a medical examination during the time period 31 May-11 June 2010. An announcement was put up in local official buildings and information given on radio and TV news. Also, inhabitants were contacted by telephone by staff from the two local primary healthcare centres in the area. The majority of participants were examined at temporary medical offices at a community centre or at a primary healthcare centre; a few were examined in their homes.

\section{Medical and psychological examination}

A physician interviewed and examined all participants. The physicians in charge were specialists in family medicine and respiratory medicine. Former and present physical and psychological health was explored. Participants were asked if they experienced any change in health or new symptoms that they related to the ash and the volcanic eruption. The medical history of young children was obtained from their parents. In case of abnormal findings, the participants were referred to their Primary Health Care Centre for further examination and treatment.

\section{Spirometry}

The forced expiratory volume in one second $\left(\mathrm{FEV}_{1}\right)$ and the forced vital capacity (FVC) values were obtained by spirometry in all participants 5 years or older, according to the American Thoracic Society criteria in the same way and by the same fieldworkers as had conducted the Burden of Obstructive Lung Disease (BOLD) multicentre study in Iceland. ${ }^{17}{ }^{18}$ The spirometry was conducted by trained and certified personnel, and the medical examination was conducted by doctors, all from the Landspitali University Hospital.

Briefly, testing was conducted with the participant in a sitting position wearing a nose clip and a disposable mouthpiece using the NDD Easy One spirometer (NDD Medizintechnik, Zurich, Switzerland). Prebronchodilator and postbronchodilator tests were carried out, with separate measurements performed before and $\geq 15$ min after two puffs of salbutamol (200 $\mu \mathrm{g})$. The primary reference equations used are derived from the third United States National Health and Nutrition Examination Survey (NHANES III) for adult Caucasians. ${ }^{19}$

The criteria for chronic obstructive pulmonary disease (COPD) are defined by the Global Initiative of Chronic Obstructive Lung Disease. ${ }^{17}$ COPD GOLD stage I was defined as $\mathrm{FEV}_{1} / \mathrm{FVC}$ ratio $<0.7$ after bronchodilation and GOLD stage II as $\mathrm{FEV}_{1} / \mathrm{FVC}$ ratio $<0.7$ and $\mathrm{FEV}_{1}$ $\leq 80 \%$ predicted after bronchodilation. Reversibility of airway obstruction was calculated as a change in $\mathrm{FEV}_{1}$ and expressed as a change in percentage $(\Delta \%)$.

For analysis of the spirometry results in those older than 40 years, a subset of the BOLD cohort ${ }^{18}$ was used as a control group, with three age- and gender-matched controls from the BOLD (random general) population for each participant exposed to volcanic ash.

\section{Questionnaires}

Participants older than 18 years were asked to fill out questionnaires with questions about physical health, mental health, exposure to volcanic ash, experience of earthquakes, rumbling and smell from the volcano, and use of protective face masks and glasses. If necessary, the questionnaires were read to them by researchers.

Respiratory health before the eruption was assessed by the European Community Respiratory Health Survey (ECRHS) II Questionnaire. ${ }^{20}$ From the main ECRSH Questionnaire, we used questions about wheeze, cough and phlegm prevalence, history of respiratory- and heart disease (questions number 1-3, 6-10 and 14, and question 7 from the screening questionnaire).

The participants were also asked if they had experienced other respiratory or eye symptoms, muscular pain, fatigue, nausea, headache, stomach pain or insomnia before and/or after the eruption started. If the symptoms had started after the eruption, they were asked to quantify how much these symptoms affected their daily life on a 3-point scale (rather little, rather much and very much).

Parents answered seven questions about respiratory symptoms, headache, stomach ache, insomnia, anxiety, depression and behavioural changes in children younger than 18 years. If these symptoms had started after the eruption, they were asked to quantify them on a threelevel scale.

There were also questions about medical emergencies, use of medication, injuries, and accidents related to the eruption.

Mental health was assessed with three different psychometric scales, which all had previously been translated into Icelandic and used in other studies. When measuring psychological morbidity in relationship with the eruption, we used the General Health Questionnaire (GHQ-12), ${ }^{21} 22$ the Depression Anxiety Stress Scale (DASS), ${ }^{23}$ and the Post-Traumatic Stress Disorder (PTSD) Symptom Scale, Self-Report version (PSS-SR). ${ }^{24} 25$ Each questionnaire was evaluated, and, if inadequately answered, excluded.

For GHQ-12, a score of more than 2 was considered indicative of experiencing more mental distress than usual (Bimodal score)..$^{21}$

For PSS-SR, a score of more than 14 considered indicative of likelihood of PTSD symptoms in the participants. $^{24} 25$

For DASS, a score was given for each of the three dimensions addressed in the questionnaire. A score of more than 10 for depression, 8 for anxiety, and 15 for stress indicated symptom severity, from mild to extreme, as defined by Lovibond and Lovibond. ${ }^{23}$ DASS and PSSSR questionnaires were not administered on the first day of the study, but participants were given the option of filling out the questionnaires and mailing them. 
Participants were asked how they had experienced ash fall, heard or been awakened by noise from the volcano, felt earthquakes, smell or limited vision outside due to ash fall at their homes; how many days they had to stay inside because of ash fall; how many hours they usually worked outdoors and if they had used protective equipment. Finally, participants were asked if they had received help or services from a number of organisations and institutions, and if they were satisfied with it.

Smoking history was investigated by asking participants if they had ever smoked, and if they were current smokers. Based on this information, the participants were classified into never-smoker, former smoker and current smoker.

\section{Statistical analysis}

All data were entered into a database by one observer. The analysis was mainly descriptive, and the primary outcome measure was prevalence in percentage $(\%)$ of the total number of answers in the given category. In comparisons between groups, we used Student t test and $\chi^{2}$ test. Individuals with incomplete data were not excluded from the study, but non-replies to any single questions were excluded from individual analyses. We used SPSS software V. $18^{26}$ and R. ${ }^{27}$

\section{RESULTS}

Altogether 207 out of 223 individuals (93\%) who lived in the study area at the time of the eruption participated in the study. Local health workers, who recruited the participants, reported that inhabitants of two of about 80 farms had refused to participate, and 14 individuals who had initially signed up did not participate.

The most common reason for non-participation reported to the recruiters was either 'being busy', 'not having any health problems' or 'old age' (reported by relatives). Of the 207 participating residents, 40 were younger than 18 years. Most of them, 202 (98\%) were medically examined, 164 adults and 38 children. The same proportion was tested with spirometry, and 156 adults were tested both before and after bronchodilation. All adults received questionnaires about symptoms and general health (GHQ-12). PSS-SR and DASS were administered to 150 people. Main demographic characteristics, symptom, and smoking rates reported by adults are shown in table 1 . The survey included 40 children younger than 18 years, of which 21 (53\%) were girls.

The age distribution of all participants is given in figure 2.

\section{Physical examination}

The physician's judgement was that $126(62 \%)$ of the participants were healthy. In the physician interview, 26 (13\%) of adults reported history of asthma or other chronic respiratory diseases, $32(16 \%)$ reported symptoms and signs other than respiratory and 27 (13\%) participants indicated a history of mental symptoms. Asthma rates reported to physicians were similar to those reported in questionnaires. Of those with a history of asthma or other respiratory diseases, $38 \%$ had a normal spirometric test, but $39 \%$ reported worsening of the disease when exposed to ash (table 1). Some reported to physicians that upper respiratory symptoms subsided when avoiding exposure by staying inside, wearing dust masks, and also that falling 'fresh' ash was more bothersome than 'older' ash re-suspended by wind. Farming was reported as the main occupation $(63 \%)$ of adult participants.

\section{Spirometry}

Among the 202 participants who underwent spirometry, $37(18 \%)$ were found to have impaired respiratory function by the examining physician.

Table 1 Demographic characteristics and questionnaire-reported symptoms of participants who all lived close to the Eyjafjallajökull volcano $(n=167)$

\begin{tabular}{|c|c|c|c|}
\hline & All & Men & Women \\
\hline $\mathrm{N}(\%)$ & & $83(50)$ & $84(50)$ \\
\hline Mean age $\pm S D$ (years) & $52 \pm 17$ & $54 \pm 18$ & $50 \pm 17$ \\
\hline $\mathrm{BMI} \pm \mathrm{SD}\left(\mathrm{kg} / \mathrm{m}^{2}\right)$ & $30.0 \pm 7$ & $29.1 \pm 5$ & $30.8 \pm 8$ \\
\hline \multicolumn{4}{|l|}{ Smoking, $\mathrm{n}(\%)$} \\
\hline Never & $103(62)$ & $53(64)$ & $50(60)$ \\
\hline Former & $34(20)$ & $18(22)$ & $16(19)$ \\
\hline Current & $24(14)$ & $11(13)$ & $13(14)$ \\
\hline Self-reported asthma or COPD*, n (\%) & 28 (17) & $10(12)$ & $18(21)$ \\
\hline \multicolumn{4}{|l|}{ Respiratory symptoms, n (\%) } \\
\hline Throat and upper airway irritation or dryness & $83(50)$ & $35(42)$ & $48(57)$ \\
\hline Cough & $58(35)$ & $28(34)$ & $30(35)$ \\
\hline Shortness of breath or tightness of chest & $43(26)$ & $20(24)$ & $23(27)$ \\
\hline \multicolumn{4}{|l|}{ Other symptoms, $\mathrm{n}(\%)$} \\
\hline Eye irritation & $41(25)$ & $17(20)$ & $24(29)$ \\
\hline Headaches & $15(9)$ & $8(10)$ & $7(8)$ \\
\hline Nausea and stomach aches & $12(7)$ & $7(8)$ & $5(6)$ \\
\hline
\end{tabular}


Figure 2 Age distribution of the study participants $(n=207)$ from the Eyjafjallajökull area investigated from 31 May to 11 June 2010.

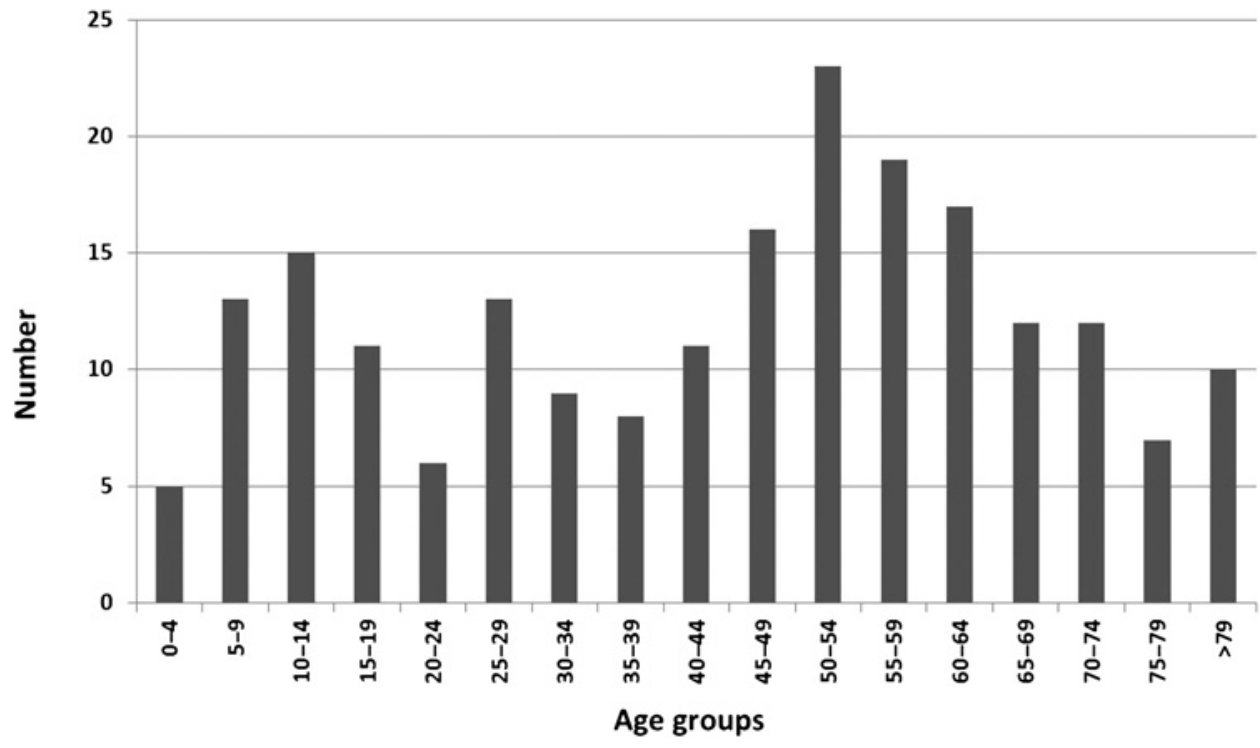

Participants aged 40 years or older had on average a higher $\mathrm{FEV}_{1}$ than the reference group $(\mathrm{p}=0.003)$, and they also showed less airflow reversibility $(p<0.0001)$. The rates of chronic cough and phlegm were similar in the study participants and the reference group $(8 \%-$ $10 \%)$. Smoking was more common in the reference group than the volcano-exposed participants $(\mathrm{p}<0.01)$. After bronchodilation, $20 \%$ of those aged 40 years or older fulfilled the criteria for COPD stage I or higher, which was identical to that found among the general population reference group (table 2). ${ }^{18}$

The 35 children who were tested with spirometry had a normal per cent of predicted $\mathrm{FEV}_{1}(102 \% \pm 19 \%$; mean, one SD) and FVC (104\% $\pm 17 \%)$. Altogether four had $\mathrm{FEV}_{1} \%$ predicted lower than $85 \%$; two of these had pre-existing asthma and revealed symptoms when examined ( $\mathrm{FEV}_{1} 48 \%$ and $76 \%$, respectively), the other two were previously healthy, but both had symptoms of upper airway virus infection $\left(\mathrm{FEV}_{1} 71 \%\right.$ and $81 \%$, respectively) when examined.

\section{Questionnaires}

Almost half of the adult participants (43\%) experienced symptoms from the upper airways and eyes during the ash fall. Almost everybody or 153 of 161 (96\%) found facial mask and glasses protective against respiratory and

Table 2 Spirometry results, smoking status, reported chronic respiratory diseases and symptoms among participants aged $>40$ years compared to an age- and gender-matched reference group from the general population

\begin{tabular}{|c|c|c|c|}
\hline Spirometry & $\begin{array}{l}\text { Participants }(n=128) \text {, } \\
\text { Mean } \pm S D\end{array}$ & $\begin{array}{l}\text { Controls }(n=384) \text {, } \\
\text { Mean } \pm S D\end{array}$ & $p$ (t test) \\
\hline $\mathrm{FEV}_{1} \%$ predicted $^{*}$ & $94 \pm 15$ & $90 \pm 17$ & 0.003 \\
\hline FVC \% predicted & $98 \pm 15$ & $95 \pm 14$ & 0.105 \\
\hline $\mathrm{FEV}_{1} / \mathrm{FVC} \%$ predicted & $96 \pm 9$ & $93 \pm 11$ & 0.004 \\
\hline$\Delta \mathrm{FEV}_{1}$ (\% increase after bronchodilation) & $3 \pm 7$ & $4 \pm 7$ & $<0.000$ \\
\hline COPD & n (\%) & n (\%) & $\mathrm{p}\left(\chi^{2}\right.$ test $)$ \\
\hline GOLD stage I or higher $\dagger$ & $25(20)$ & $77(20)$ & 1 \\
\hline $\begin{array}{l}\text { GOLD stage II or higher } \\
\text { Self-reported }\end{array}$ & $15(12)$ & $42(11)$ & 0.87 \\
\hline \multicolumn{4}{|l|}{ Smoking } \\
\hline Current & $19(15)$ & $154(40)$ & \multirow[t]{3}{*}{$0.00^{*}$} \\
\hline Former & $31(24)$ & $159(41)$ & \\
\hline Never & $76(59)$ & $71(18)$ & \\
\hline Ever asthma & $21(20)$ & $74(19)$ & 0.30 \\
\hline Ever COPD & $3(2)$ & $6(2)$ & 0.70 \\
\hline Chronic phlegm & $11(8)$ & 38 (10) & 0.61 \\
\hline Chronic cough $\ddagger$ & $11(8)$ & $43(11)$ & 0.33 \\
\hline
\end{tabular}


eye symptoms when staying outdoor during ash fall. All participants of the study were exposed to ash fall at their homes, and almost all $(88 \%)$ had to stay inside at least 1 day and one third (34\%) for 6 days or more, which may explain some of the mental distress and child behavioural problems. Also, avoiding exposure by staying in the well-isolated houses may have kept symptom rates down. Almost everyone (98\%) had heard the explosions from the mountain at their home, and $53 \%$ had woken up at night because of noise, but there was no obvious geographical pattern to this. The most common self-reported symptoms in adult participants are shown in table 1. Men and women had similar rates of symptoms, except that women tended to report more throat and upper airway irritation $(p=0.06$, Student $\mathrm{t}$ test).

Women reported more frequently mental health deterioration than men, according to the GHQ and DASS, and the highest rates were found in those between 35 and 49 years of age (table 3). Symptoms of posttraumatic stress syndrome (PSS-SR) were found in $7 \%$ of participants and were more common among women than men and in those slightly older (50-64 years old). Very little effect on mental health was reported in the age group 18-34 years.

Table 4 shows the proportions of participants experiencing mental distress by level of exposure (experience of the volcanic eruption). Experiencing a feeling of helplessness or fear for the lives of others or oneself during the eruption period was associated with higher rates of likely PTSD symptoms. The frequency of mental distress (as measured by the GHQ) was significantly $(p<0.05)$ higher in those who had been awakened by noise.

Symptoms of depression and anxiety (DASS) were more common among those who had experienced earthquakes and had thought that their lives were in danger (table 4).
Many children of school age were not in the area during the heaviest ash fall. A boarding school outside the affected region invited the Eyjafjallajökull children to stay for some weeks. By the time the health survey was carried out, most were in the area. Nevertheless, 13 $(28 \%)$ of parents reported in the questionnaires that their child had experienced throat or upper airway irritation symptoms (data not shown). Eight (13\%) reported headaches, while three parents $(7 \%)$ reported that their child or children had had nausea or stomach pain during the eruption. Of the 40 participating children, five had a history of asthma and they all reported in the medical interview that they had had more symptoms during the ash fall and needed more antiasthmatic medication than usual. Regarding mental distress, 39\% of participants with children reported increased worries or anxiety in their children, $18 \%$ reported increased behaviour problems and $16 \%$ reported sleep-related problems.

\section{DISCUSSION}

In a well-defined rural population that had been exposed to volcanic ash particles with a substantial inhalable fraction for several weeks during the Eyjafjallajökull eruption, we found only a small degree of physical health impairments soon after the eruption. No hospital admissions, fatalities or life-threatening or serious symptoms or diseases that could be attributed to the eruption were found in this study cohort. From the answers to the questionnaires, we could conclude that compared to the general population sample from the BOLD study, the study participants reported a similar prevalence of respiratory symptoms and obstructive lung disease. Some symptoms of mental distress were found in this study.

In our study, we contacted the whole population living closest to the volcano and had a high participation rate $(93 \%)$. According to the recruiters, some non-participators

\begin{tabular}{|c|c|c|c|c|c|}
\hline & Likelihood of PTSD* & General Health $\dagger$ & Depression $\ddagger$ & Anxiety $\ddagger$ & Stress $\ddagger$ \\
\hline Number of valid replies & 138 & 151 & 132 & 130 & 133 \\
\hline Cases $\S$ & $10(7 \%)$ & $59(39 \%)$ & $9(7 \%)$ & $11(8 \%)$ & $9(7 \%)$ \\
\hline Women & $8 / 62(13 \%)$ & $38 / 78$ (49\%) & $6 / 71(8 \%)$ & $8 / 69$ (12\%) & $7 / 71(10 \%)$ \\
\hline Men & $2 / 76(3 \%)$ & $21 / 71$ (30\%) & $3 / 62(5 \%)$ & $3 / 61(5 \%)$ & $2 / 62(3 \%)$ \\
\hline \multicolumn{6}{|l|}{ Age categories } \\
\hline $18-34$ & $0 / 27(0 \%)$ & $9 / 32$ (29\%) & $0 / 27(0 \%)$ & $1 / 27(4 \%)$ & $0 / 26(0 \%)$ \\
\hline $35-49$ & $3 / 36(8 \%)$ & $24 / 39$ (62\%) & $5 / 35(14 \%)$ & $5 / 33(15 \%)$ & $6 / 34(17 \%)$ \\
\hline $50-64$ & $6 / 41(15 \%)$ & $18 / 47(38 \%)$ & $3 / 39(8 \%)$ & $3 / 40(8 \%)$ & $2 / 40(5 \%)$ \\
\hline$>64$ & $1 / 34(3 \%)$ & $8 / 33(24 \%)$ & $1 / 31(3 \%)$ & $2 / 30(7 \%)$ & $1 / 33(3 \%)$ \\
\hline \multicolumn{6}{|c|}{ Lived in the evacuation zone } \\
\hline Yes & $4 / 59(7 \%)$ & $26 / 69(38 \%)$ & $6 / 58(10 \%)$ & $7 / 57$ (12\%) & $5 / 59(8 \%)$ \\
\hline No & $6 / 79(8 \%)$ & $33 / 82(40 \%)$ & $3 / 75(4 \%)$ & $4 / 73(5 \%)$ & $4 / 73(5 \%)$ \\
\hline
\end{tabular}


Table 4 Mental symptoms and experiences during the eruption of Eyjafjallajökull

\begin{tabular}{|c|c|c|c|c|c|}
\hline & $\begin{array}{l}\text { Likelihood of PTSD }+ \\
(n=138)\end{array}$ & $\begin{array}{l}\text { General } \\
\text { health } \neq(n=151)\end{array}$ & $\begin{array}{l}\text { Depression } \S \\
(n=132)\end{array}$ & $\begin{array}{l}\text { Anxiety§ } \\
(n=130)\end{array}$ & $\begin{array}{l}\text { Stress } \S \\
(n=133)\end{array}$ \\
\hline \multicolumn{6}{|c|}{ Exposure at residence ('From your residence, did you experience any of the following?') $\ddagger$} \\
\hline \multicolumn{6}{|c|}{ Was awakened by noise $(n=157)$} \\
\hline Yes & $5 / 66(8 \%)$ & $38 / 75(51 \%)^{*}$ & $3 / 63(5 \%)$ & $6 / 64(9 \%)$ & $3 / 63(5 \%)$ \\
\hline No & $5 / 63(8 \%)$ & $16 / 66(24 \%)$ & $5 / 61(8 \%)$ & $4 / 58(7 \%)$ & $5 / 60(8 \%)$ \\
\hline \multicolumn{6}{|c|}{ Felt earthquakes $(n=155)$} \\
\hline Yes & $5 / 42(12 \%)$ & $27 / 51(53 \%)$ & $2 / 39(5 \%)^{*}$ & $3 / 38(8 \%)$ & $2 / 39(5 \%)^{*}$ \\
\hline No & $4 / 85(5 \%)$ & $27 / 89(30 \%)$ & $5 / 84(6 \%)$ & $7 / 83(8 \%)$ & $5 / 84(6 \%)$ \\
\hline \multicolumn{6}{|c|}{ Traumatic experiences ('Did you during the eruption...') } \\
\hline \multicolumn{6}{|c|}{ Think your life was in danger $(n=144)$} \\
\hline Yes & $1 / 6(17 \%)^{*}$ & $2 / 4(50 \%)$ & $1 / 5(20 \%)^{*}$ & $0 / 5(0 \%)$ & $1 / 4(25 \%)$ \\
\hline No & $8 / 126(6 \%)$ & $42 / 123(34 \%)$ & $8 / 123(7 \%)$ & $11 / 120(9 \%)$ & $7 / 123(6 \%)$ \\
\hline \multicolumn{6}{|c|}{ Think that someone else's life was in danger $(n=139)$} \\
\hline Yes & $4 / 19(21 \%)^{*}$ & $9 / 16(56 \%)$ & $3 / 18(17 \%)$ & $3 / 17(29 \%)$ & $3 / 17(18 \%)^{*}$ \\
\hline No & $5 / 108(5 \%)$ & 33/107 (31\%) & $5 / 105(5 \%)$ & $6 / 103(6 \%)$ & $4 / 105(4 \%)$ \\
\hline \multicolumn{6}{|c|}{ Feel helpless $(n=143)$} \\
\hline Yes & $9 / 30(30 \%)^{*}$ & $20 / 27(74 \%)^{*}$ & $8 / 30(27 \%)^{\star}$ & $8 / 29(28 \%)^{*}$ & $7 / 28(25 \%)^{*}$ \\
\hline No & $0 / 101(0 \%)$ & $24 / 100(24 \%)$ & $1 / 98(1 \%)$ & $3 / 96(3 \%)$ & $1 / 99(1 \%)$ \\
\hline \multicolumn{6}{|c|}{ Feel afraid $(n=142)$} \\
\hline Yes & $4 / 17(24 \%)^{\star}$ & $10 / 17(59 \%)^{*}$ & $5 / 18(28 \%)^{\star}$ & $4 / 16(25 \%)^{*}$ & $3 / 17(18 \%)$ \\
\hline No & $5 / 113(4 \%)$ & $34 / 108(31 \%)$ & $4 / 108(4 \%)$ & $6 / 107(6 \%)$ & $5 / 108(5 \%)$ \\
\hline
\end{tabular}

reported not having any health problems, so the symptom rates presented here may be overestimated. There may also be a recall bias, so that those who are worried about their health are more likely to participate and recall symptoms. On the other hand, some vulnerable individuals may have chosen not to participate or had left the most affected area, which may cause us to underestimate the symptom rates.

To facilitate comparisons with other studies, we used standardised methods in both the medical examinations and questionnaires, as well as the spirometry in this survey. However, the population is small $(\mathrm{N}=207$, of which 167 were adults) and due to stressful circumstances during the test period, not all participants completed the questionnaire, which limited the statistical power of our analyses.

The participants from the Eyjafjallajökull area had better lung function than the general population sample, most likely due to a much lower prevalence of smoking. They also had less obstructed airways when tested again after use of a bronchodilator, probably because those with asthma had already increased their bronchodilator treatment during the ash fall. Also, the general population reference sample lived in urban and suburban areas, whereas the Eyjafjallajökull area is predominantly rural. The children had normal spirometry measurements. Previous studies have not found changes in lung function in children after volcanic ash exposure, but asthma hospitalisation rates have been seen to increase after several eruptions, ${ }^{11}{ }^{12}$ and a dose-response has also been found in a Japanese study of asthmatic adults who were exposed to volcanic ash. ${ }^{28}$

Intermittent symptoms in the eyes and upper respiratory organs were very common, but they could be prevented by wearing eye protection and face masks, or avoiding exposure by staying inside. Facial masks and glasses for eye protection were made widely and freely available by the public health authorities. These protective equipment were in plentiful supplies purchased for the swine flu epidemic the previous year. Icelandic houses are generally quite well insulated with windows that shut tightly and seemed to offer some protection.

It was recorded in several of the medical examination reports that people found the ash more irritating in the beginning of the eruption, perhaps because fresh ash particles can have chemical compounds on the surface, which are later washed away. 23

In a study of the ash from Eyjafjallajökull, Horwell et $a l^{2}$ found most samples to have little potential for damaging health. The ash contained a negligible amount of crystalline silica, and though one sample showed some cytotoxicity in in vitro studies, the report concluded that the ash was unlikely to have an effect at the levels to which people were actually exposed.

The first results from a study of lung tissue samples and samples from the gastrointestinal tract of animals brought to slaughter from the affected area in the autumn of 2010 did not reveal any significant pathology. ${ }^{29}$ 
During the first days of the eruption, precautions for individuals with respiratory disease were issued throughout much of Europe, both by national health authorities but also by the WHO. ${ }^{30}$ Symptom surveillance studies, however, have shown a slight increase in the number of individuals on the European continent seeking medical help for certain symptoms in the period when the region was affected by ash. ${ }^{31} 32$

In our study, $39 \%$ of participants reported some symptoms of mental distress, as measured by the GHQ. A high GHQ score was associated with feeling helpless or afraid or being awakened by noises from the volcano. The rate of GHQ cases in this study was more than twice as many as in a 2004 study of Icelandic farmers where $17 \%$ scored above the reference value for mental distress in the GHQ. ${ }^{33}$ However, in a Japanese study of a population exposed to a volcanic eruption, $66 \%$ were found to suffer from mental distress, but this population had been evacuated and were unable to return to their home region for years. ${ }^{14}$ Only half of the participants in this study population were evacuated, and then only for a few days.

The proportion of participants who exhibited symptoms of post-traumatic stress $(7 \%)$ was similar to that found following a large earthquake in the south of Iceland in 2008. ${ }^{34}$ When the eruption was still active, there were substantial disturbances in people's daily routine. Some of the fatigue and stress indicated by the high prevalence of mental distress may be attributed to the increased workload during the eruption and at the same time the uncertainty about one's own health, the health of others, the livestock and the future. In addition, our results showed that increased mental distress might partly be explained by the extent of experience of volcanic phenomena, as it was associated with having experienced earthquakes related to the eruption or experiencing threat to one's own life or that of others. On the other hand, those who are distressed may experience these phenomena more strongly during an eruption. Information about the possible health effects of the ash was needed for the affected individuals. Therefore, early in the eruption, collaboration was established with national as well as international experts from the WHO and EU, and the International Volcanic Health Hazards Network, whose pamphlets were translated into Icelandic and distributed widely. ${ }^{35}$ Trauma response teams on behalf of the Red Cross were present in the evacuation and community centres, and a number of community meetings were held to inform the affected population.

\section{CONCLUSIONS}

During the time when volcanic ash was falling from the Eyjafjallajökull eruption, the majority of participants experienced symptoms from eyes and upper airways. Those with underlying obstructive lung disease were particularly vulnerable; half of the asthmatic adults and all the asthmatic children had more pronounced symptoms during the eruption.
Our results indicate that public health measures were effective in relieving symptoms. Recommendation to avoid exposure by either staying inside or wearing dust protection masks and glasses when outdoors during the ash fall or storms may have contributed to mitigation of irritation and symptoms.

During a volcanic ash fall, intensive medical attention should be aimed at vulnerable individuals with underlying respiratory diseases and known mental disorders.

Little is known about long-term health effects of exposure to volcanic ash, but continuous surveillance and research is necessary as the ash is likely to remain in the environment for some years to come. A follow-up study would be helpful in interpreting the spirometry results, but no severe health outcomes could be associated with the eruption in this study.

Acknowledgements We thank Olof Arnadottir and Helga Thorbergsdottir, RN, South Iceland Primary Health Care Centre; Berglind Gudmundsdottir, psychologist, Landspitali-University Hospital; Edda Bjork Thordardottir, PhD student, University of Iceland; Gudrun Pétursdottir, PhD, University of Iceland Centre for Sustainability Studies; Kristinn Tomasson, MD, Administration of Occupational Safety and Health in Iceland; Urdur Njardvik, lector in psychology, University of Iceland; Ossur Ingi Emilsson, Cand. Med., University of Iceland; Halldora Brynjolfsdottir, Hildur Ragnarsdottir, Kristin Bara Jorundsdottir and Sigrun Gudmundsdottir, research specialists, Landspitali-University Hospital; Elísabet Magnusdottir, research assistant, University of Iceland and Agust Gunnar Gylfason, project manager in risk management, Icelandic civil protection service for their assistance in conducting this study.

Contributors All authors were involved in designing the study, interpreting the results and drafting the article. TG and BB conducted the medical examinations, HKC and AH implemented the questionnaires, TBK recruited the participants, TT analysed the data on the ash and ash fall and HB initiated this study and collected all data.

Funding Funded by the Ministry of Welfare. The Health Authorities.

\section{Competing interests None.}

Patient consent Obtained.

Ethics approval Icelandic Health Authorities. According to Icelandic legislation (Act no. 19/1997 on Health Security and Communicable Diseases), incidents concerning public health threats are to be investigated without delay such as urgent outbreak investigations. Ethics approval may take some time and could not possibly be obtained before this investigation started

Provenance and peer review Commissioned according to the Act on Health Security and Communicable Disease Control No. 19/1997. Externally peer reviewed

Data sharing statement The authors are willing to share all available data. There are additional unpublished data on spirometric measurements available if requested.

\section{REFERENCES}

1. Stohl A, Prata AJ, Eckhardt S, et al. Determination of time- and height-resolved volcanic ash emissions for quantitative ash dispersion modeling: the 2010 Eyjafjallajökull eruption. Atmos Chem Phys Discuss 2011;11:5541-88.

2. Horwell CJ, Baxter P, Hillman SE, et al. Respiratory health hazard assessment of ash from the 2010 eruption of Eyjafjallajökull volcano, Iceland. A summary of initial findings from a multi-centre laboratory study. In: The International Volcanic Health Hazard Network Report 2010. http://www.ivhhn.org/images/pdf/iceland_ash_health_report. pdf (accessed Nov 2010).

3. Gislason SR, Hassenkam T, Nedel S, et al. Characterization of Eyjafjallajökull volcanic ash particles and a protocol for rapid risk assessment. Proc Natl Acad Sci USA 2011;108:7307-12.

4. Thorsteinsson T, Johannsson T, Petursdottir G. High levels of particulate matter due to ash plume and ash re-suspension following 
the Eyjafjallajökull eruption. Geophys Res Abstr 2011;13. EGU201111546, 2011. EGU General Assembly 2011.

5. Thorsteinsson T, Johannsson T, Stohl A, et al. High levels of particulate matter in Iceland due to direct ash emissions by the Eyjafjallajökull eruption and re-suspension of deposited ash. $J$ Geophys Res 2012:117:9 PP.

6. Hansell AL, Horwell CJ, Oppenheimer C. The health hazards of volcanoes and geothermal areas. Occup Environ Med 2006:63:149-56.

7. Hansell AL, Oppenheimer C. Health hazards from volcanic gases: a systematic literature review. Arch Environ Occup Health 2004:59:628-39.

8. Longo BM, Rossignol A, Green JB. Cardiorespiratory health effects associated with sulphurous volcanic air pollution. Public Health 2008;122:809-20.

9. Longo BM, Yang W. Acute bronchitis and volcanic air pollution: a community-based cohort study at Kilauea volcano, Hawai'i, USA. J Toxicol Env Health 2008;71:1565-71.

10. Durand M, Wilson JG. Spatial analysis of respiratory disease on an urbanized geothermal field. Environ Res 2006;101:238-45.

11. Naumova EN, Yepes H, Griffiths JK, et al. Emergency room visits for respiratory conditions in children increased after Guagua Pichincha volcanic eruptions in April 2000 in Quito, Ecuador observational study: time series analysis. Environ Health 2007;6:21.

12. Horwell CJ, Baxter PJ. The respiratory health hazards of volcanic ash: a review for volcanic risk mitigation. B Volcanol 2006;69:1-24.

13. Shore JH, Tatum EL, Vollmer WM. Evaluation of mental effects of disaster, Mount St. Helens eruption. Am J Public Health 1986;76 (Suppl): $76-83$

14. Ohta $\mathrm{Y}$, Araki K, Kawasaki N, et al. Psychological distress among evacuees of a volcanic eruptionfarm in Japan: a follow-up study. Psychiat Clin Neuros 2003;57:105-11.

15. Sigmundsson FS, Hreinsdottir A, Hooper T, et al. Intrusion triggering of the 2010 Eyjafjallajökull explosive eruption. Nature 2010;468:426-30.

16. Larsen G, Höskuldsson A. Ash layer from Eyjafjallajökull 17.4.2010 I Institute of Earth Sciences, University of Iceland (In Icelandic). 2010. http://jardvis.hi.is/Apps/WebObjects/HI.woa/swdocument/1015817/ 2010-04-17_GLARE+\%C3\%B6skulag_Eyjafj\%C3\%B6Il.pd (accessed Oct 2011)

17. Buist AS, McBurnie MA, Vollmer WM, et al. International variation in the prevalence of COPD (the BOLD Study): a population-based prevalence study. Lancet 2007;370:741-50.

18. Benediktsdottir B, Gudmundsson G, Jörundsdottir KB, et al. Prevalence of COPD in Iceland-the BOLD study (In Icelandic). Laeknabladid 2007;93:471-7.
19. Hankinson JL, Odencrantz JR, Fedan KB. Spirometric reference values from a sample of the general U.S. population. Am J Respir Crit Care Med 1999;159:179-87.

20. Burney PG, Luczynska C, Chinn S, et al. The European community respiratory health survey. Eur Respir J 1994;5:954-60.

21. Goldberg D, Williams P. A User's Guide to the General Health Questionnaire. Oxford: NFER-Nelson Publishing Company Ltd, 1988.

22. Goldberg D, Gater R, Sartorius N, et al. The validity of two versions of the GHQ in the WHO study of mental illness in general health care. Psychol Med 1997;27:191-7.

23. Lovibond SH, Lovibond PF. Manual for the Depression Anxiety Stress Scales. 2nd edn. Sydney: Psychology Foundation, 1995.

24. Rose S, Andrews B, Green J, et al. Brief screening instrument for post-traumatic stress disorder. Br J Psychiat 2002;181:158-62.

25. Foa EB, Riggs DS, Dancu CV, et al. Reliability and validity of a brief instrument for assessing post-traumatic stress disorder. J Trauma Stress 2006;6:459-73.

26. Team RDC. R: a Language and Environment for Statistical Computing. Vienna, Austria. 2011. http://www.R-project.org/

27. IBM. SPSS for Windows. Version 18. New York, USA. 2009

28. Shimizu Y, Dobashi K, Hisada T, et al. Acute impact of volcanic ash on asthma symptoms and treatment. Int $\mathrm{J}$ Immunopathol Pharmacol 2007;2:9-14.

29. Sigurðardóttir Ó. Impact of the volcanic eruption in Eyjafjallajökull on the health of farm animals I the Institute for Experimental Pathology Keldur, University of Iceland (In Icelandic). 2011. http://www.keldur.is/ ahrif_eldgossins_i_eyjafjallajokli_heilsufar_bufjar (accessed Apr 2011)

30. World Health Organization. Volcanic Ash Cloud Over Europe. 2010. http://www.euro.who.int/en/what-we-do/health-topics/environmentalhealth/air-quality/volcanic-ash-cloud-over-europe (accessed Dec 2010)

31. Elliot AJ, Singh N, Loveridge $P$, et al. Syndromic surveillance to assess the potential public health impact of the Icelandic volcanic ash plume across the United Kingdom, April 2010. Euro Surveill 2010;15. http://www.eurosurveillance.org/ViewArticle.aspx?Articleld=19583 (accessed Oct 2010).

32. Brand $\mathrm{H}$, Krafft $\mathrm{T}$. The Icelandic ash cloud and other erupting health threats: what role for syndromic surveillance? Eur J Public Health 2010;20:367-8

33. Tomasson K, Gudmundsson G. Mental health and well-being in Icelandic farmers (In Icelandic). Laeknabladid 2009;95:763-9.

34. Guðmundsdottir B. Impact of the May 29th 2008 earthquake on the inhabitants of south Iceland (In Icelandic). Laeknabladid 2009;95:46.

35. International volcanic health hazards network. Guidelines on preparedness before, under and after an ashfall (Icelandic version). 2010. http://www.ivhhn.org/images/pamphlets/ preparedness_icelandicpamphlet.pdf (accessed Dec 2011). 